\title{
Identifying Technology Competency of Green Skills in the Fourth Revolution Industries amongst Teacher Trainee
}

\author{
Syarina Ramli, Mohamad Sattar Rasul ${ }^{*}$, Haryanti Mohd Affandi \\ Faculty of Education,Universiti Kebangsaan Malaysia, 43600 UKM Bangi, Malaysia
}

Received July 28, 2020; Revised October 7, 2020; Accepted October 30, 2020

\section{Cite This Paper in the following Citation Styles}

(a): [1] Syarina Ramli, Mohamad Sattar Rasul, Haryanti Mohd Affandi. "Identifying Technology Competency of Green Skills in the Fourth Revolution Industries amongst Teacher Trainee," Universal Journal of Educational Research, Vol. 8, No. 11A, pp. 33 - 42, 2020. DOI: 10.13189/ujer.2020.082105.

(b): Syarina Ramli, Mohamad Sattar Rasul, Haryanti Mohd Affandi (2020). Identifying Technology Competency of Green Skills in the Fourth Revolution Industries amongst Teacher Trainee. Universal Journal of Educational Research, 8(11A), 33 - 42. DOI: 10.13189/ujer.2020.082105.

Copyright $\bigcirc 2020$ by authors, all rights reserved. Authors agree that this article remains permanently open access under the terms of the Creative Commons Attribution License 4.0 International License

\begin{abstract}
Green Skills are a gateway to turning Fourth Industrial Revolution (4IR) into a low carbon economy and innovation. Technology competency of Green Skills is one of the competencies that are essential to the driving force behind effective teaching and learning. Thus, this study seeks to identify the readiness level technology competency of green skills in 4IR amongst TVET teacher trainee. This study will also identify the needed level technology competency of green skills in 4IR towards TVET teacher trainee from the perspective of educator. A total of 154 teacher trainees and 44 educators were selected as samples by using disproportionate stratified random technique. The questionnaire has been developed and adapted from the Model of Green Skills Competency by Pavlova and Skills in 4IR consists of 8 indicators. Mean score and standard deviation for statistical measurement were used to report the findings. Findings from the analysis show that the readiness level technology competency of green skill in 4IR amongst TVET teacher trainee are at a moderate level. However, the needed level technology competency of green skills in 4IR towards TVET teacher trainee from the perspective of educator are at high level. This shows that technology competency of green skills is important to teacher trainee in order to face the challenge of Fourth Industrial Revolution (4IR). Findings from this study will benefit Institute of Teacher Education and Ministry of Education in order to prepare teacher trainees as well as in-service teachers with technology green skills
\end{abstract}

so that our Sustainable Development Goals will be achieved and equip themselves in a way of Fourth Industrial Revolution.

Keywords Sustainable Development, Fourth Industrial Revolution (4IR), Green Skills, Technology Competency

\section{Introduction}

Technology competence in the Fourth Industrial Revolution is also increasingly interlinked; as a convergence of digital, physical and biological realms in particular (Ruohomaa, Kantola \& Salminen, 2018). The 4IR for sustainable development is designed to demonstrate the potential of Innovations of the Fourth Industrial Revolution and their applications to the most pressing environmental issues in the world. (Oosthuizen, 2017). Hence, by ensuring inclusive and equitable quality education and promoting opportunities for lifelong learning for all, is the fourth sustainable development goal on the UN agenda. Achieving this goal involves diverse projects and effective approaches in various educational areas. Therefore, Education for Sustainable Development (ESD) is characterized as education, according to UNESCO-UNEVOC (2017), which promotes changes in knowledge, skills, values and attitudes to make a more 
prosperous and equitable society. ESD as education for sustainable development(Hensley, 2017) and green skills are key to the Fourth Industrial Revolution towards a low-carbon economy and innovation (4IR) (Mansell, Philbin \& Konstantinou, 2019).

The issue of solid waste management, water systems, wastage of energy and environmental resources and unemployment is addressing the important of having technology competency of green skills in the industrial revolution 4.0. This is because Green skills can control resource efficiency through smart networks that will improve the quality of life as well as protect the economy of a country. With the latest digital technology, it can bridge the gap between rural and urban as well as avoid marginalizing the poor. Innovation of the Fourth Industrial Revolution will be integral to provide a better quality of life to the environment especially in urban areas. With the help of IoT, blockchain and VR can detect water quality and solid waste types for recycling processes, and educate the public on proper practices to minimize water and solid waste consumption (Herweijer et al., 2017).

This technology competency in green skills is important because it pushes the economic growth of the country towards sustainable development by generating human capital that can economically, socially and politically develop the country without neglecting environmental aspects (Dlimbetova et al., 2016). Thus, technology competency of green skills is one of the constructs studied to see to what extent this technology competence plays a role in generally shaping green skills model for TVET teacher trainee. However, study in Vietnam's Greening TVET, teachers must be educated on green issues TVET(Klaus-Dieter \& Huyen, 2016). Because of the lack of capable TVET teachers, teachers need to be prepared with requirements for green skills such as technologies applications, technical skills and knowledge, pedagogical components, workplace experiences and also relevant environmental knowledge. They also had to teach and instill green skills to increase their students' awareness of the environment(Diep \& Hartmann, 2016)

According to Pant \& Delhi (2015), teaching environmental subjects with outdoor technologies encouraged students to observe nature more closely and thus increase their knowledge of the environment), improve their environmental knowledge and attitudes, and to "overcome one of today's fundamental challenges for environmental education, namely, learners' alienation from nature" (Cheng et al., 2013, p. 105). The possibility of witnessing real life phenomena outside the classroom through the use of technology handheld devices allows children to create personal relations to the natural world which, on the other hand, is suggested to influence the attitudes of learners towards nature (Heinonen, 2015). As a conclusion, (Pant and Delhi 2015) summarizes that novel technology-mediated education offer a great potential for environmental education. Since the students are already advanced users of the devices, they feel natural to participate in direct experiences with a portable computer in nature.

In Malaysia, Education for Sustainable Development (ESD) stresses the incorporation of key sustainable development concerns in education and learning, i.e. climate change, catastrophe risk reduction, biodiversity, poverty reduction and sustainable consumption. This initiative includes successful pedagogy to ensure a participatory learning and teaching approach that will inspire and encourage future leaders to ensure sustainability of their social structures.(Reza 2016). Malaysia has adopted the ideals of Agenda 21 as one of the essential documents on sustainable development into its national planning process. Nevertheless, the efficacy of these teaching-learning systems and their successful pedagogical methods and endpoints are not adequately guaranteed. It is because, the technology competency is crucial needed in order to make sure there are no mismatch skill in industrial revolution era.(The Ministry of Human Resources; Skills development Department; National University of Malaysia 2017) . Besides that, agenda of Asia-Pacific Training Kuala Lumpur 2015 also highlights the needs for green skills for the sustainability of TVET program development in one of its eight agendas. (UNESCO and Kementerian Pendidikan 2015).

The government is seeking to implement green technologies that can be seen from the point of view of two innovation elements.: the process of design and development of green technology. School students are taught and encouraged to create something: design and produce products that are environmentally friendly and practical for our country. At a higher level, we can develop technologies that can produce useful articles without wasting resources such as electricity and water. The new eco-friendly design must be practical that can be commercialized for local and export needs (Arasinah et al., 2016). Therefore, competence in ICT technology and knowledge is critical for a TVET teacher trainee, as it helps teaching and learning progress smoothly, creates interesting teaching environments, helps teachers prepare teaching materials and enables teachers to explore new knowledge (Abdullah et al. 2016). This is also supported by study of Alwi, Kamis \& Rus (2017), where teachers must have technology competency of green skills in ensuring that the teaching and learning process is smooth and updated with the current technologies. For example, in the subject of TVET, Technology Design, competent teachers in the technology green skills will expose to the students on how to manage solid waste systematically and monitoring the waste management by using technologies in 4IR like IoT, big data and so on.

Teachers, in particular trainee teachers, therefore need to be strengthened by mastery of technological competence, because without technological competence, teachers find it difficult to cope with learning that involves the use of 
technology in line with 4ir education, especially in the field of TVET related to design subjects. The goal of this paper is therefore to define the readiness level technology competence of green skills in the Fourth Industrial Revolution (4IR) from the perspective of the TVET teacher trainee as well as the appropriate level technology competence of green skills needed by the educator for the TVET teacher trainee at the Institute of Teacher Education. Teacher trainees have been selected as a focus study as they play a key role in achieving the 2030 Sustainable Development Goals SDGs) for quality education as a prerequisite for sustainable learning and human growth.

\section{Conceptual Framework}

The conceptual framework of this study is consistent and relevant to the applicable literature in this field. Figure 1 is the diagram of the conceptual framework which will be discussed in this article.

Theory of Ecological Modenisation founded by Huber, Simonis and Janicke of Germany, Arthur Mol, and Spaargaren of the Netherlands in the 90s are explained the basis concept for the formulation of environmental policy and as a basic theory of Sustainable Development Model. It is the core of an industry which can be said to be a guideline in ensuring that the environment can be taken care of well, while ensuring economic growth is not stunted (Mol et al. 2002). In the context of this article, this theory would expand on some of the elements relevant to green skills competence in the 4IR and also in education system especially for teacher trainee.

In this theory, there are five elements which are environment education, green technology, eco-innovation, zero-waste concept and environmental awareness has strong impetus in ensuring economic development and environmental sustainability can be preserved well or vice versa.

The Green Skills Competency Model is a study model of Pavlova (2016) where green skills are the agenda for the transition of competencies in the field of TVET. This model requires a balanced of four competencies which are cognitive competency, technology competency, intrapersonal competency and interpersonal competency. However, in this study it just focuses on technology competency. In technology competency, the elements of the construct are environmental technology knowledge, environmental technology management, environmental awareness, analysis skills; ICT application by minimising the use of materials in physical form, innovation skills to identify opportunities and create new strategies to address green challenges; solving problems on economic, social and green technology issues; and innovative solutions for green technology strategies (Pavlova, 2016).

According to Mohd Zuhair Azuar (2015), elements of green technology skills need to be applied into the Engineering Technology syllabus (now rebranded to the subject of Basic Sustainability) where the aim is to produce creative and technology literate students and teachers and to give society knowledge of the importance of environmental sustainability through education. For example, TVET students from automotive course, need not only to learn how to build or repair traditional types of cars that have harmful consequences, but also to have the expertise to operate different types of vehicles, hybrid models. Meanwhile, green skills in designing green concept houses, using environmentally friendly building materials and utilities are required for students involved in building design and construction courses (Paryono, 2017).

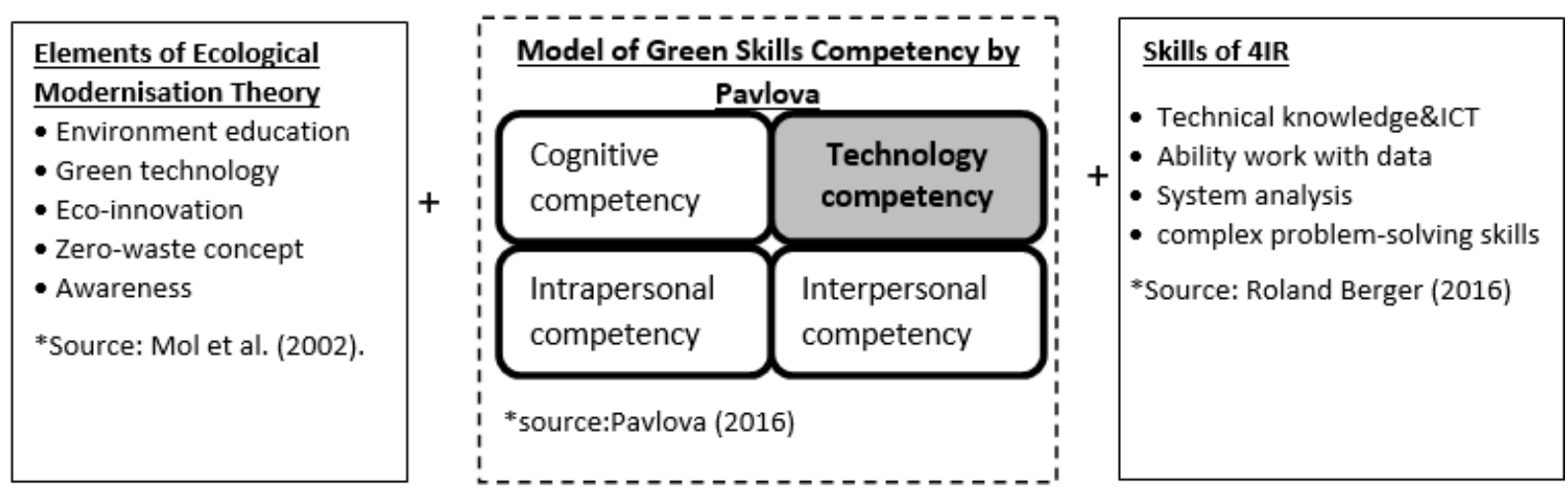

Figure 1. Conceptual Framework 
Thus, from the Model of Green Skills Competency, technology competency is one of the important aspects of green skills development (Pavlova, 2016). Technological competency is the ability to create and use a particular field of technology effectively, which is gained through extensive experimentation and learning in its research, development and employment in production (Fai \& von Tunzelmann, 2001). According to Pavlova (2016), technology competencies in green skills encompasses elements of quantification and monitoring of either waste, energy or water management systems of either waste, energy or water, selection and acquisition of goods and services from external sources that are appropriate in terms of quality and environmental impact, material use and impact quantification, impact assessment, minimization of environmental impact, minimization of materials used, what can be recycled, environmental laws and regulations, environmental risk management and how learnt skills contribute to greening of industry. Therefore, the technology competencies in green skills are important to proficient by TVET teacher trainee as well as needed for them.

This study also integrates the basic skills of the industrial revolution 4.0 to produce a variety of green skills competencies based on new technologies that impact on various disciplines, economies and industries. Wilfried Aulbur, CJ \& Bigghe (2016) emphasized four key skills relevant to technology competency in the industrial revolution 4.0 which are technical knowledge \& IC, ability work with data, system analysis and complex problem-solving skills. In conjunction, all these skills are embedded in the Model of Green Skills Competency. Thus, it is emerging to combine and rephrase those skills to develop the indicator of items.

\section{Methodology}

\section{Research Design}

This research - employs a survey research design that intended to assess the perspective of teacher trainee regarding to the level of competency of technology green skills in the fourth revolution industries (4IR). The needed of technology competency of green skills in 4IR for teacher trainee also will assess in this study from the perspective of educator.

\section{Participants}

The population of this study consisted of TVET teacher trainee and educators from Institute of Teacher Education in Malaysia. Of the 27 campus, there are three campus that offer TVET courses which are Institute of Teacher Education Tuanku Bainun Campus, Institute of Teacher Education Temenggong Ibrahim Campus dan Institute of Teacher Education Technical Education Campus. The sampling process was performed by a disproportionate stratified random technique. Raosoft Software has been used to get the minimum sample from the population targeted.

From the 202 TVET teacher trainee and 47 educators surveyed, about 154 (76.2\%) teacher trainee and 44 (93.6\%) educators were choosen as a sample. This amount of sampling was adequate since it just 133 minimum sample required based on Raosoft Software with margin error 5\% and confidence level 95\%.

Table 1. Demographics of TVET Teacher Trainee

\begin{tabular}{|c|c|c|c|c|}
\hline No. & Demographics & Item & Frequency & Percentage \\
\hline \multirow{2}{*}{1.} & \multirow{2}{*}{ Gender } & Male & 63 & $40.9 \%$ \\
\hline & & Female & 91 & $59.1 \%$ \\
\hline \multirow{3}{*}{2.} & \multirow{3}{*}{ Ages } & $18-23$ & 153 & $99.4 \%$ \\
\hline & & $24-29$ & 1 & $0.6 \%$ \\
\hline & & 30 above & 0 & $0 \%$ \\
\hline \multirow{3}{*}{3.} & \multirow{3}{*}{ Campus } & Temenggong Ibrahim & 43 & $27.9 \%$ \\
\hline & & Pendidikan Teknik & 97 & $63.0 \%$ \\
\hline & & Tuanku Bainun & 14 & $9.1 \%$ \\
\hline \multirow{3}{*}{4.} & \multirow{3}{*}{ PISMP intake } & $2015 / 2016$ & 49 & $31.8 \%$ \\
\hline & & 2018 & 71 & $46.1 \%$ \\
\hline & & 2019 & 34 & $22.1 \%$ \\
\hline \multirow[t]{2}{*}{5.} & \multirow[t]{2}{*}{$\begin{array}{l}\text { Practical teaching } \\
\text { experience }\end{array}$} & $\begin{array}{l}\text { Practical teaching undergone and } \\
\text { taught RBT subjects } \\
\text { Practical teaching undergone but } \\
\text { has not taught RBT subjects }\end{array}$ & 49 & $31.8 \%$ \\
\hline & & Not yet practical teaching & 105 & $68.2 \%$ \\
\hline
\end{tabular}


Table 1 shows the frequency and percentage of TVET teacher trainee who were respondents in this study. Based on the table, it was found that the number of male respondents was $63(40.9 \%)$ while the number of female respondents was 91 (59.1\%). In terms of age, almost the majority of 153 (99.4\%) respondents involved are between 18 to 23 years, while the remaining 1 respondent $(0.6 \%)$ is in the range of 24 to 29 years.

The distribution of participating respondents is from three Institute of Teacher Education that are from Campus of Temenggong Ibrahim as many as 43 (27.9\%), Campus of Technical Education 97 (63.0\%) and Campus of Tuanku Bainun as many as 14 (9.1\%). In terms of student intake, 2015/2016 intake consisted of a total of 49 (31.8 percent) of the Ijazah Sarjana Muda Perguruan Program (PISMP). While a total of 71 (46.1 percent) was PISMP intake in 2018 and the remaining 34 (22.1 percent) were PISMP intake in 2019. Meanwhile for practical teaching experience, a total of 49 (31.8\%) respondents have undergone teaching training and have taught related subjects TVET, while the remaining 105 (68.2\%) have not yet undergone teaching training. In total, a total of 154 respondents (76.2\%) responded to this questionnaire.
Table 2 indicates the frequency and percentage of respondents who are the educators. There were 32 (72.7\%) male respondents while 12 (23.7\%) were female respondents. Educators participating in this study had more than 10 years of experience with the highest percentage of 32 (72.7\%) while the remainder with experience between 5 and 10 years are 12 (27.3\%).

The participating respondents are from the three selected Institute of Teacher Education which are Temenggong Ibrahim Campus as many as 8 (18.2\%), Technical Education Campus as many as 29 (65.9\%) and Tuanku Bainun Campus as many as 7(15.9\%).The Agriculture field, Accounting and Entrepreneurship field reported the highest number of 10 respondents in terms of expertise (22.7\%). Followed by the 8 (18.2 percent) field of mechanical engineering, the 6 (13.6 percent) and 5 (11.4 percent) field of Civil engineering and Electrical and Electronic engineering. In the Hospitality field, the number of educators involved in this study was 2 (4.5 per cent). The fields that reported the lowest number and percentage were Household Economics which was 1 (2.3\%), Engineering Development 1 (2.3\%) and Nutrition Science sector 1 (2.3\%) respectively.

Table 2. Demographics of educator

\begin{tabular}{|c|c|c|c|c|}
\hline No. & Demographics & Item & Frequency & Percentage \\
\hline \multirow{2}{*}{1.} & \multirow{2}{*}{ Gender } & Male & 32 & 72.7 \\
\hline & & Female & 12 & 23.7 \\
\hline \multirow{3}{*}{2.} & \multirow{3}{*}{ Experience in related field } & $<5$ years & 0 & 0 \\
\hline & & $6-10$ years & 12 & 27.3 \\
\hline & & $>10$ years & 32 & 72.7 \\
\hline \multirow{3}{*}{3.} & \multirow{3}{*}{ Campus } & Temenggong Ibrahim & 8 & 18.2 \\
\hline & & Pendidikan Teknik & 29 & 65.9 \\
\hline & & Tuanku Bainun & 7 & 15.9 \\
\hline \multirow{9}{*}{4.} & \multirow{9}{*}{ Expert in field } & Agriculture & 10 & 22.7 \\
\hline & & Civil engineering & 6 & 13.6 \\
\hline & & Electrical and electronic engineering & 5 & 11.4 \\
\hline & & Mechanical engineering & 8 & 18.2 \\
\hline & & Design and Technology & 1 & 2.3 \\
\hline & & Accountancy and Entrepreneurship & 10 & 22.7 \\
\hline & & Science Nutrition & 1 & 2.3 \\
\hline & & Household economics & 1 & 2.3 \\
\hline & & Hospitality & 2 & 4.5 \\
\hline
\end{tabular}




\section{Instruments}

This study used quantitative approach whereby questionnaires were distributed to the respondents using Google Form. The assessment is based on a quantitative approach using statistical procedures. Quantitative research can be done through descriptive studies or inferential (Chua, 2015). Chua (2015) stated basic descriptive statistics such as frequency, percentage, mean, standard deviation and the distribution of scores were used to report the findings. In this study, data from the questionnaire were collected and the scores mean and standard deviation were used to report the findings. A Total of 9 questions was used and analyzed. The questionnaire has been developed and adapted from the Model of Green Skills Competency by (Pavlova 2016) and key skills in 4ir by Wilfried Aulbur, Arvind CJ (2016). The detail of how the construct in questionnaire was developed has been explained in Table 3.

Table 3. Details of Indicator developed in questionnaire

\begin{tabular}{|c|c|c|c|c|}
\hline No & Sources & Indicator & Details item in questionnaires & Scale \\
\hline \multirow[b]{2}{*}{1.} & $\begin{array}{l}\text { Model of Green Skills Competency by } \\
\text { Pavlova } \\
\text {-Technology competency }\end{array}$ & $\begin{array}{c}\text { Environmental } \\
\text { technology } \\
\text { knowledge } \\
\end{array}$ & \multirow{2}{*}{$\begin{array}{l}\text { Environmental technology } \\
\text { knowledge: Ability to explain } \\
\text { the concepts of solid waste, } \\
\text { energy, and water monitoring } \\
\text { using blockchain technology, } \\
\text { artificial intelligence and IoT }\end{array}$} & \\
\hline & $\begin{array}{l}\text { 4IR key skills: } \\
\text {-Technical knowledge \& ICT } \\
\text {-Ability work with data } \\
\text {-System analysis }\end{array}$ & $\begin{array}{l}\text { Current technology } \\
\text { applied }\end{array}$ & & \\
\hline \multirow[b]{2}{*}{2.} & $\begin{array}{l}\text { Model of Green Skills Competency by } \\
\text { Pavlova } \\
\text {-Technology competency }\end{array}$ & $\begin{array}{l}\text { Environmental } \\
\text { technology } \\
\text { knowledge }\end{array}$ & \multirow{2}{*}{$\begin{array}{l}\text { Environmental technology } \\
\text { knowledge: Ability to describe } \\
\text { solid waste, energy, and water } \\
\text { quantification applications } \\
\text { using blockchain technology, } \\
\text { artificial intelligence and IoT. }\end{array}$} & \\
\hline & $\begin{array}{l}\text { 4IR key skills: } \\
\text {-Technical knowledge \& ICT } \\
\text {-Ability work with data } \\
\text {-System analysis }\end{array}$ & $\begin{array}{l}\text { Current technology } \\
\text { applied }\end{array}$ & & \\
\hline \multirow{2}{*}{3.} & $\begin{array}{l}\text { Model of Green Skills Competency by } \\
\text { Pavlova } \\
\text {-Technology competency }\end{array}$ & \multirow{2}{*}{$\begin{array}{l}\text { Environmental } \\
\text { technology } \\
\text { management }\end{array}$} & \multirow{2}{*}{$\begin{array}{l}\text { Environmental technology } \\
\text { management: Knowledge of } \\
\text { solid waste management system }\end{array}$} & \\
\hline & $\begin{array}{l}\text { 4IR key skills: } \\
\text {-System analysis } \\
\text {-Management skills }\end{array}$ & & & \\
\hline \multirow[t]{2}{*}{4.} & $\begin{array}{l}\text { Model of Green Skills Competency by } \\
\text { Pavlova } \\
\text {-Technology competency }\end{array}$ & \multirow{2}{*}{$\begin{array}{l}\text { Environmental } \\
\text { awareness }\end{array}$} & \multirow{2}{*}{$\begin{array}{l}\text { Environment awareness: } \\
\text { Selection of goods and services } \\
\text { meet environmental standards }\end{array}$} & Using ordinal scale: \\
\hline & $\begin{array}{l}\text { 4IR key skills: } \\
\text {-emotional intelligence }\end{array}$ & & & 5 point Likert scale \\
\hline \multirow[t]{2}{*}{5.} & $\begin{array}{l}\text { Model of Green Skills Competency by } \\
\text { Pavlova } \\
\text {-Technology competency }\end{array}$ & \multirow{2}{*}{$\begin{array}{l}\text { Identified green } \\
\text { technology } \\
\text { challenges }\end{array}$} & \multirow{2}{*}{$\begin{array}{l}\text { Application of ICT } \\
\text { Technology: Minimize the use } \\
\text { of materials in physical form }\end{array}$} & 1- Strongly Disagree \\
\hline & $\begin{array}{l}\text { 4IR key skills: } \\
\text { •Technical knowledge \& ICT } \\
\end{array}$ & & & 3- Neutral \\
\hline \multirow[b]{2}{*}{6.} & $\begin{array}{l}\text { Model of Green Skills Competency by } \\
\text { Pavlova } \\
\text {-Technology competency }\end{array}$ & \multirow[b]{2}{*}{ Innovation skills } & \multirow{2}{*}{$\begin{array}{l}\text { Innovation skills: Cultivate the } \\
\text { concept of eco-innovation }\end{array}$} & 4- Agree \\
\hline & $\begin{array}{l}\text { 4IR key skills: } \\
\text { - problem solving skills } \\
\text {-Technical knowledge \& ICT }\end{array}$ & & & 5- strongiy Agree \\
\hline \multirow{2}{*}{7.} & $\begin{array}{l}\text { Model of Green Skills Competency by } \\
\text { Pavlova } \\
\text {-Technology competency }\end{array}$ & \multirow{2}{*}{ System skills } & \multirow{2}{*}{$\begin{array}{l}\text { System Skills: E-waste system } \\
\text { skills }\end{array}$} & \\
\hline & $\begin{array}{l}\text { 4IR key skills: } \\
\text {-system skills } \\
\text {-Technical knowledge \& ICT }\end{array}$ & & & \\
\hline \multirow{2}{*}{8.} & $\begin{array}{l}\text { Model of Green Skills Competency by } \\
\text { Pavlova } \\
\text {-Technology competency }\end{array}$ & \multirow{2}{*}{ Problem solving skill } & \multirow{2}{*}{$\begin{array}{l}\text { Problem solving skill: Ability to } \\
\text { explain the concept of the use of } \\
\text { technology in waste } \\
\text { management }\end{array}$} & \\
\hline & $\begin{array}{l}\text { 4IR key skills: } \\
\text {-complex problem-solving skills } \\
\text {-Technical knowledge \& ICT }\end{array}$ & & & \\
\hline \multirow{2}{*}{9.} & $\begin{array}{l}\text { Model of Green Skills Competency by } \\
\text { Pavlova } \\
\text {-Technology competency }\end{array}$ & \multirow{2}{*}{$\begin{array}{l}\text { Element across } \\
\text { curriculum }\end{array}$} & \multirow{2}{*}{$\begin{array}{l}\text { Element across curriculum } \\
\text { Can relate with elements of } \\
\text { green industries technology } \\
\text { with other topics or subject } \\
\text { teaching. (how everything is } \\
\text { connected) }\end{array}$} & \\
\hline & $\begin{array}{l}\text { 4IR key skills: } \\
\text {-complex problem-solving skills } \\
\text {-Technical knowledge \& ICT }\end{array}$ & & & \\
\hline
\end{tabular}




\section{Reliability and Validity}

The face and content validity of this instrument was carried out by three experts from Higher Education Institute in the field of technical and vocational. The reliability of this instrument was been measured with internal consistency, Cronbach Alpha coefficient 0.82. The five-point Likert scale has been used to measure the questions that represent perspectives of teacher trainee towards the readiness level of technology competency of green skills in 4IR and the level needed technology competency of green skills towards teacher trainee from the educator's perspective.

\section{Measurement}

Finally, basic descriptive statistic such as mean scores and standard deviation were used to report the findings. Based on the interpretive mean values proposed by Landell (1977), each element studied will be at the strength of its interpretation value indicating that the level of technology competency green skills in 4IR. Though, the mean score between 1.00-2.33, shows low level interpretation, mean score between 2.34-3.67 shows intermediate and 3.68-5.00 show high level of interpretation.

\section{Results}

Tabulated data from Table 4 shows that there were nine (9) elements of technology green skills that have been considered in order to achieve the competencies of technology green skills. The 5-point Likert scale was used to identify the readiness and importance level of green skills competency element in the fourth industrial revolution.

Table 4. The readiness and importance level of technology green skills competency in 4IR

\begin{tabular}{|c|c|c|c|c|c|c|c|}
\hline \multirow[b]{2}{*}{ No. } & \multirow[b]{2}{*}{ Items } & \multicolumn{3}{|c|}{ TVET Teacher trainee } & \multicolumn{3}{|c|}{ Educators } \\
\hline & & $\begin{array}{l}\text { Mean Score } \\
\text { (m) }\end{array}$ & $\begin{array}{l}\text { Standard } \\
\text { Deviation } \\
\text { (SD) } \\
\end{array}$ & $\begin{array}{c}\text { Interpretation } \\
\text { readiness level of } \\
\text { competency }\end{array}$ & $\begin{array}{c}\text { Mean } \\
\text { Score } \\
(\mathbf{m}) \\
\end{array}$ & $\begin{array}{l}\text { Standard } \\
\text { Deviation } \\
\text { (SP) }\end{array}$ & $\begin{array}{c}\text { Interpretation } \\
\text { importance level } \\
\text { of competency }\end{array}$ \\
\hline 1. & $\begin{array}{l}\text { Environmental knowledge: } \\
\text { Ability to explain the concepts } \\
\text { of solid waste, energy, and } \\
\text { water monitoring using } \\
\text { blockchain technology, } \\
\text { artificial intelligence and IoT }\end{array}$ & 2.86 & 1.048 & Intermediate & 4.07 & 0.661 & High \\
\hline 2. & $\begin{array}{l}\text { Environmental knowledge: } \\
\text { Ability to explain applications } \\
\text { for solid waste, energy and } \\
\text { water quantification using } \\
\text { blockchain technology, } \\
\text { artificial intelligence and IoT. }\end{array}$ & 2.73 & 0.970 & Intermediate & 3.93 & 0.759 & High \\
\hline 3. & $\begin{array}{l}\text { Environmental management: } \\
\text { Knowledge of solid waste } \\
\text { management system }\end{array}$ & 2.84 & 1.006 & Intermediate & 3.86 & 0.765 & High \\
\hline 4. & $\begin{array}{l}\text { Environment awareness: } \\
\text { Selection of goods and services } \\
\text { meet environmental standards }\end{array}$ & 3.36 & 0.942 & Intermediate & 4.09 & 0.640 & High \\
\hline 5. & $\begin{array}{l}\text { Application of ICT } \\
\text { Technology: Minimize the use } \\
\text { of materials in physical form }\end{array}$ & 3.42 & 0.975 & Intermediate & 4.09 & 0.640 & High \\
\hline 6. & $\begin{array}{l}\text { Innovation: Cultivate the } \\
\text { concept of eco-innovation }\end{array}$ & 3.45 & 0.915 & Intermediate & 4.16 & 0.526 & High \\
\hline 7. & $\begin{array}{l}\text { System analysis: E-waste } \\
\text { system skills }\end{array}$ & 3.38 & 1.097 & Intermediate & 3.95 & 0.680 & High \\
\hline 8. & $\begin{array}{l}\text { Problem solving skill: Ability } \\
\text { to explain the concept of the use } \\
\text { of technology in waste } \\
\text { management }\end{array}$ & 3.14 & 1.055 & Intermediate & 3.95 & 0.776 & High \\
\hline 9. & $\begin{array}{l}\text { Element across curriculum } \\
\text { Can relate with elements of } \\
\text { green industries technology } \\
\text { with other topics or subject of } \\
\text { teaching. (how everything is } \\
\text { connected) }\end{array}$ & 3.48 & 0.909 & Intermediate & 4.09 & 0.603 & High \\
\hline & Total average & 3.18 & 0.991 & Intermediate & 4.02 & 0.672 & High \\
\hline
\end{tabular}


Based on Table 5, the interpretation of the mean score by Landell (1977) shows that all the nine elements technology competency of green skills amongst TVET teacher trainee is at a moderate level with a mean score of 3.18 (SD = 0.991). Meanwhile, the level technology competency of green skills needed towards TVET teacher trainee is at high level with a mean score of $4.02(\mathrm{SD}=0.672)$. From the perspective of TVET teacher trainee, the readiness element of "Environmental knowledge: Ability to explain applications for solid waste, energy and water quantification using blockchain technology, artificial intelligence and IoT" should be noted as it shows the lowest mean score of 2.73 (SP $=0.970$ ) while the educator's level of need for TVET teacher trainee is at a high level with a mean score of 3.93 (SD = 0.759). However, the readiness elements of "Element across curriculum- can relate with elements of green industries technology with other topics or subject of teaching (how everything is connected)" amongst TVET teacher trainee shows the highest score mean compare to others element with a score mean of $3.48(\mathrm{SD}=0.909)$ and the importance level is at a high level with a score mean of 4.09 (0.603)

\section{Discussion}

Findings from this study shows that most TVET teacher trainees at the Institute of Teacher Education have a moderate readiness level of technology competency of green skills consisting of elements of environmental knowledge, environmental management, environmental awareness, application of ICT and technology, innovation, system analysis, problem solving and element across curriculum. This is worrying as most of these green skills elements of technology are highly needed for TVET teacher trainees. Technology competency of green skills is important because it is the driving force of the country's economic growth towards sustainable development by creating human capital that can improve the country's economy, social and political without neglecting environmental aspects (Dlimbetova et al. 2016). It is also realigned with the concept of Pavlova (2016) where competencies in green skills encompasses elements of environmental awareness and readiness in the development of sustainable development.

From the findings, the element of ICT application and technology shows the moderate readiness level by TVET teacher trainee while it is in high demand from the perspective of educator. In this regard, this element should be polished by TVET teacher in order to teach and facilitate, as well as to improve learning, productivity, and performance. According to Norazlinda Saad \& Sankaran (2020), proficiency of technology seems relevant to many aspects of the teaching profession, such as lesson preparation and development of teaching kids. These is important as by applying ICT and technology, teacher will minimize the use of materials in physical. Other aspects that impact teacher decisions to introduce technology into teaching and learning activities are teachers' beliefs about the way the subject should be taught and the skills associated with teacher competence in managing classroom activities using technology tools and devices. Therefore, teachers must be able to apply the technological knowledge and skills required in professional job roles and responsibilities in order to achieve the expected outputs.

In addition, all teacher trainees should have the innovation element, as they will foster the idea of eco-innovation for their school students. This is because this item also shows the highest level required from an educator's point while it is moderate readiness level by TVET teacher trainee. The innovation elements are important to teacher trainee as until posting to school, they do need to train themselves as a real teacher with an element of system analysis (Izzat, Siti Mistima \& Fariza, 2020). E-waste wants teachers to learn how the program functions, so that they can explain to their potential students, for environmental education. Ability to illustrate the idea of using technology in waste management would give teacher trainee the elements of problem-solving skills. As the Fourth Industrial Revolution (4IR) gathers pace, teacher needs the ability to solve complex problems effectively in real-time using a unique and carefully designed solution (Naidoo and Singh-Pillay,2020). They must be able to face anything risk and know how to analyze the future obstacle in education. Therefore, the technology competencies in green skills are important to proficient by TVET teachers. In addition to this, problem-solvers can work independently from higher supervision. They also learn from those mistakes, and habitually debrief their processes to create more efficient and economical solutions(Watanabe, 2016). For this reason, as suggested in the study conducted by Mohd Zuhair Azuar (2015), elements of green technology skills need to be added to the syllabus of Engineering Technology (now rebranded to the subject of Basic Sustainability) where the main objective is to produce students and teachers who are creative and competent in technology, and to make society aware of the importance of environmental sustainability.

In overall, the level of importance towards competency of technology green skills amongst TVET lecturers in Fourth Industrial Revolution (4IR) was at high level while the readiness level was at a moderate level. It seemed perfectly reasonable result as an increasingly competitive environment to provide better education specially to face revolution of education 4.0, higher education institution should focus on improving and preparing students with technology abilities. One of the important factors which can contribute to improving technology abilities is teacher professional competencies. Teacher should have a wide and deep knowledge and technical skills regarding the courses they teach (Prasetio and Dindi 2017). 


\section{Conclusions}

Green skills are crucial for sustainable development to ensure the Fourth Industrial Revolution is turned into a low-carbon economy and innovation. Meanwhile, education plays a major role in improving green economy skills, 4IR skills, social skills and environmental competences. Thus, technology competency is one of the important aspects of green skills development. Technology competency of green skills in fourth industrial revolution encompasses elements of quantification and monitoring waste, energy or water management systems, energy or water selection and acquisition of goods and services from external sources that are appropriate in terms of quality and environmental impact, material use and impact quantification, innovation in waste management, minimization of environmental impact, minimization of materials used, what can be recycled, environmental risk management and how learnt skills contribute to greening of industry. This study has significant implications in terms of practice, field of education and application where technology competency of green skill is much needed to complement the low-carbon economy in line with the needs of industry 4.0. Teachers with technical competence in green skills will be comfortable in the use of technology, especially in subjects related to design. With the technological skills they possess, they will use their skills to reduce the use of natural resources and switch to the use of more digital materials. Thus, findings from this study will shed some light among TVET teacher trainees and educators on the initial technology competency of green skills in the Fourth Industrial Revolution (4IR). In addition, this paper focuses on TVET teacher trainee at the Institute of Teacher Education so that it is important to concentrate on this institution as teacher trainee shares green skills in their teaching skills and is a role model in shaping new generations to support humanity, the environment and the economy. Next for future research, it is recommended that potential studies concentrate on the development of instruments assessing the degree of technical competence in green skills and module development on how to apply green technology skills to trainee teachers.

\section{Acknowledgement}

We wish to thanks Universiti Kebangsaan Malaysia under the Program STEM and Minda with grant code GG-2017-017 and Faculty of Education Research Fund with grant code GG-2019-045 for funding this research.

\section{REFERENCES}

[1] Abdullah, Abdul Halim et al. 2016. "Factors Preventing Malaysian Teachers from Using Information and
Communication Technology (ICT) in Teaching Mathematics.” 2016 4th International Conference on Information and Communication Technology, ICoICT 2016 (May).

[2] Chua, Yan Piaw. 2015. "Kaedah Dan Statistik Penyelidikan: Kaedah Penyelidikan.” (May): 12-14.

[3] Diep, Phong Chi, and Martin Hartmann. 2016. "Green Skills in Vocational Teacher Education - a Model of Pedagogical Competence for a World of Sustainable Development." TVET@Asia (6): 1-19.

[4] Heinonen, Paavo. 2015. "Modern Portable Technology in Environmental Education as Part of Formal Curriculum Teaching.” (July).

[5] https://suomi.luma.fi/wp content/uploads/2017/02/heinonen-2015.pdf.

[6] Hensley, Nathan. 2017. “Approaches to Education for Sustainable Development (ESD) in Kesennuma, Japan A Qualitative Case Study of Continuous Challenges Faced by Educators Pursuing Sustainability in Their Teaching.” (45). https://www.edu.su.se/polopoly_fs/1.341643.1502351334!/ menu/standard/file/Hensley 2017 ICE Thesis Final Manuscript.pdf.

[7] Izzat, Siti Mistima, \& Fariza. 2020. "The Impacts of Learning Analytics on Primary Level Mathematics Curriculum.” Universal Journal of Educational Research 8(5): 95-99. https://doi.org/10.13189/ujer.2020.081914

[8] Klaus-Dieter, and Dang Thi Huyen. 2016. “Greening TVET in Vietnam:Sustainable Development, Green Economy and The Role of Greening TVET.” Vietnamese-German Development Cooperation in TVET.

[9] Mansell, Authors Paul, Simon P Philbin, and Efrosyni Konstantinou. 2019. "Infrastructure Projects ' Impact On Sustainable Development - Case Study Of A Water-Utility Company.” Otmc Conference.

[10] Naidoo, Jayaluxmi, and Asheena Singh-Pillay. 2020 "Exploring Mathematics Teachers' Professional Development: Embracing the Fourth Industrial Revolution.” Universal Journal of Educational Research 8(6): 2501-8. https://doi.org/10.13189/ujer.2020.080634

[11] Norazlinda Saad; and Surendran Sankaran. 2020. "Technology Proficiency in Teaching and Facilitating."

[12] Oosthuizen, Jacobus. 2017. “The Determinants Of Fourth Industrial Revolution Leadership Dexterity: A Proposed Framework For 4ir-Intelligence And Subsequent 4ir Leadership Development.” (March).

[13] Pant, Hema, and New Delhi. 2015. "Environment Education Teachers Through Technology Mediated Open and Distance Learning." : 1-7.

[14] Pavlova, Margarita. 2016. "Greening Skills : Research and Practices from Asia and the Pacific Region To Cover." EESA 2016, South Africa.

[15] Prasetio, Arif Partono, and Darin Dindi. 2017. "Lecturers ' Professional Competency and Students' Academic Performance in Indonesia Higher Education.” (August).

[16] Reza, Mohammad Imam Hasan. 2016. "Sustainability in Higher Education: Perspectives of Malaysian Higher 
Education System.” SAGE Open 6(3).

[17] Ruohomaa, Heikki, Jussi Kantola, and Vesa Salminen. 2018.

"Value Network Development in Industry 4 . 0 Environment." Advances in Human Factors, Business Management and Leadership, Advances in Intelligent Systems and Computing 1.

[18] The Ministry of Human Resources; Skills development Department; National University of Malaysia. 2017. National Conference on the 4th Industrial Revolution Skills Development (NC4IR).

[19] UNESCO-UNEVOC. 2017. “Greening TVET Curriculum and Skills - Teacher Mentoring and Peer Learning Programme ( TMPLP ).” (June).

[20] UNESCO, and Kementerian Pendidikan. 2015. Asia-Pacific Conference on Education and Training Kuala Lumpur, Malaysia, 3-5 August 2015 CONFERENCE REPORT. http://unesdoc.unesco.org/images/0023/002348/234871e.pd f.

[21] Watanabe, Lee. 2016. "The Critical 21st Century Skills Every Student Needs and Why.” wabisabi learning.

[22] Wilfried Aulbur, Arvind CJ, and Rishi Bigghe. 2016. "Skill Development for Industry 4.0.” Roland Berger. 